\title{
PANORAMMCA E EXTENSÃO DA ARBITRAGEM VOLUNTÁRLA NOS DOMÍNIOS ADMINISTRATIVO E TRIBUTÁRIO EM ANGOLA
}

\author{
PANORÂMICA E EXTENSÃO DA ARBITRAGEM VOLUNTÁRIA \\ NOS DOMÍNIOS ADMINISTRATIVO E TRIBUTÁRIO EM ANGOLA \\ Elisa Rangel Nunes ${ }^{1}$
}

\author{
Recebido em: 22/11/2017 \\ Aceito em: 29/12/2017 \\ elisarangelnunes@icloud.com
}

Resumo: O texto que se segue versa sobre a arbitragem voluntária em dois domínios inseridos no plano do Direito Público: o Direito administrativo e o Direito fiscal. Trata-se de matéria que lá fora não goza de unanimidade nos diversos ordenamentos jurídicos. Contudo, onde a arbitragem voluntária penetrou nestas duas áreas do Direito público, têm sido dados passos muito marcantes e de forma progressiva. Por cá, assiste-se a uma tímida consagração legal mais recente, que contracena com normas de alguma vetustez, principalmente no domínio do contencioso administrativo. Se ao nível da consagração legal se extrai essa timidez, ao nível da sua aplicação a aridez ou o vazio é total.

Palavras-chave: Arbitragem voluntária. Contratos administrativos. Contratos fiscais. Constituição angolana. Código do procedimento tributário.

\begin{abstract}
The following text refers to voluntary arbitration, assessed in two fields of Public Law: Administrative Law and Tax Law. We are aware that such topic is not unanimously understood in several foreign countries. Nevertheless, in the countries where voluntary arbitration has conquered space in these two fields of Public Law, major steps have been taken in a progressive way. In Angola, we can see recent legislation endorsing it shyly, going against obsolete legislation, mainly related to administrative procedure. One can see such timidity in the law, but when one looks at voluntary arbitration in public law fields in practice and one witnesses a depressing void.
\end{abstract}

Keywords: Voluntary arbitration. Administrative agreements. Tax agreements. The Angolan Constitution. The Tax procedure code.

\section{INTRODUÇÃO}

A arbitragem como forma alternativa de resolução de litígios tem vindo a conquistar um espaço cada vez mais assinalável no mundo do Direito e na aplicação da Justiça.

Primeiro no domínio do Direito privado, com raízes a raiar a ancestralidade, para depois ser experimentada no comércio internacional, onde tem ganhado "foros de cidade", ao ponto de "rasgar" domínios "nunca antes navegados", como é o caso do Direito tributário internacional. Prova disso são as convenções internacionais que têm sido celebradas para regular a resolução de litígios que possam surgir na relação tributária gerada entre Estados.

Mas no Direito interno ainda que se teimasse em não aceitar o exercício jurisdicional por particulares, já que se pensava que titularidade e exercício se esgotavam na Administração, não tardou que tal verdade fosse posta à prova, e eis que a arbitragem passou a penetrar em domínios do Direito considerados proibidos ou pelo menos proibitivos.

É sobre esse domínio de proibição, agora cada vez mais sem argumentos, que vamos tratar, partindo de uma abordagem geral do "problema" (expressão que não é minha) (1), seguindo para a

\footnotetext{
${ }^{1}$ Universidade Agostinho Neto - Sapu - Angola
} 
amostragem de como ela surge na Constituição e na lei angolanas (2), continuando pelos motivos que fizeram a arbitragem aguardar no limbo, até que um raio de luz a fez sair das trevas e ela aí vai percorrendo um caminho com algumas sinuosidades (3), analisando a consagração da arbitragem no regime jurídico de alguns contratos administrativos utilizados em Angola (4), enveredando de seguida para a admissão da arbitragem no domínio tributário na ordem jurídica interna (5), fazendo, após essa breve caminhada, algumas recomendações (6) e culminando com umas quantas conclusões.

\section{CONSIDERAÇÕES GERAIS}

Como a actividade da justiça está adstrita, exclusivamente, ao poder judicial no Estado de Direito, nunca será demais, determo-nos em algumas considerações a respeito de o exercício da jurisdição lhe estar confiado e os requisitos a que ele obedece enquanto pressuposto desse tipo de Estado. Há que não esquecer contudo, que este mundo em mudança, conduziu a que a concepção de Estado de Direito se modificasse, em virtude de se ter alterado a relação entre o Estado e a sociedade. Como refere Diogo Leite de Campos, a propósito da admissibilidade hoje da arbitragem em matéria tributária, a que chama o "problema", pelo facto de vir sendo apresentada em vários quadrantes, como "um problema" e considerada um meio alternativo, mas de natureza marginal, dado que reservada a certos domínios "privados com direitos disponíveis", enquadrada, disciplinada e controlada pelo Direito estadual, bem como pelos tribunais do Estado: "O desvio progressivo do problema é contemporâneo de uma nova concepção de Estado e de sociedade; e da posição da pessoa perante a sociedade e o Estado. Primeiro (...) pelo aprofundamento do Estado-dos-direitos (...) Depois, pelo progressivo desequilíbrio (ainda muito no seu início) das relações de força entre o Estado e a Sociedade, a favor desta. Em que o Estado aparece como um simples instrumento da sociedade civil, colocada antes e acima dele." (CAMPOS, 2008)

A jurisdição do Estado é simultaneamente uma função exercida pelo poder judicial, que como se sabe é um dos poderes do Estado, mas também constitui uma garantia, por excelência, das pessoas em face a esse mesmo Estado. (NABAIS, 2011)

As ordens jurídicas hodiernas habituadas que sempre estiveram a que a arbitragem voluntária ou jurisdição dos cidadãos incidisse na resolução de litígios do foro privado, com muita resistência têm acedido à abertura deste mecanismo a litígios que até aqui têm caído na alçada do foro judicial, por que situadas num plano do Direito distinto, ou seja com relevância ao nível do Direito público. Em casos contados assiste-se a essa abertura.

Essa resistência primeiro fez-se sentir no domínio do Direito administrativo, ao qual foram concedendo algumas prerrogativas, o que terá levado "dois séculos de progressiva penetração" (OLIVEIRA, 2007), até que actualmente o instituto da arbitragem voluntária "já não é verdadeiramente 
controverso"2 (OLIVEIRA, 2007) na resolução de litígios neste domínio do Direito. Tem-se assim que é hoje aceite a arbitrabilidade de litígios no Direito administrativo.

Mais dura de aceitar tem sido a arbitrabilidade dos litígios jus-tributários. Os limites apertados em que se tem traduzido a sua consagração nos escassos ordenamentos jurídicos que aceitaram dar esse passo, demonstram bem a resistência que tem sido oferecida. Resistência que tem radicado tanto na posição de supremacia em que tem sido colocado o Estado, como na ideia da indisponibilidade do crédito tributário, de modo a que não se dê azo, sequer a qualquer tipo de acordo entre a Administração e o contribuinte, que pretenda "alcançar a justa composição dos direitos e deveres tributários." (CATARINO;FILIPO, 2012) Como diz Ana Perestrelo de Oliveira (2007, p. 84): ao contrário do que sucedeu no Direito administrativo com a regra do favor arbitrandum, no Direito fiscal não se verificou percurso idêntico, pois tem-se entendido que fiscalidade e arbitragem são domínios "mutuamente excludentes: nem a arbitragem penetraria no Direito fiscal, nem o inverso seria possível, pois que a controvérsia tributária seria "o exacto tipo de litígio cuja apreciação é da competência exclusiva dos tribunais estaduais (...). Arbitragem e fiscalidade seriam, pois, "a água e o fogo."”

Ora, o instituto da arbitragem e a sua intervenção nestes dois domínios do Direito público que passará a ocupar-nos daqui para a frente, aconselha a que em traços largos aludamos ao conceito de jurisdição do Estado, tanto enquanto função como enquanto garantia, já que nele assenta ainda, primordialmente, a ideia de justiça.

A jurisdição do Estado é simultaneamente uma função exercida por um dos poderes do Estado e a garantia, por excelência das pessoas face a esse mesmo Estado. É a garantia das pessoas destinada a assegurar a realização dos direitos e interesses legalmente protegidos destas. Trata-se de uma garantia que acaba por revelar-se como um poder contra o Estado. (NABAIS, 2011)

Com vista a assegurar os direitos e interesses legalmente protegidos das pessoas, por estas há-de passar a capacidade de escolherem o meio adequado para a resolução de litígios em que se envolvem, até em face da morosidade e pouca especialização do poder judicial, o que parece abrir a porta à arbitragem como meio de resolução desses litígios, pelo que se poderá questionar se a sua recusa não constituirá uma violação do direito de acesso ao direito e tutela jurisdicional efectiva

\footnotetext{
2 Ana Perestrelo de Oliveira, Arbitragem de Litígios..., p. 46. Também a autora chama "problema" à aceitabilidade da arbitragem neste domínio do Direito, e explica que o modo como ele se coloca hoje fica a dever-se a dois aspectos que são fundamentais: o primeiro que se situa no plano específico do Direito da arbitragem e que se traduziu na afirmação da regra tendencial do favor arbitrandum que aponta no sentido de deverem ser comprimidos os domínios de inarbitrabilidade, que regra que veio a ganhar expressão no Direito público de forma genérica e de modo especial no Direito administrativo; o segundo que relevou ao nível do próprio Direito administrativo tendo sido determinado pela transição do carácter autoritário da Administração Pública liberal para uma Administração Pública que colabora com os particulares no procedimento administrativo como na celebração de novos contratos de Direito administrativo, que é como diz: "a conjugação da transversal liberalização da arbitragem com o fenómeno de "contratualização" da atividade administrativa que explica o estado actual da questão da arbitrabilidade dos litígios jus-administrativos".
} 
(artigo 29.. da CRA), em face de esse meio de resolução poder conduzir à obtenção de uma decisão judicial em prazo razoável ou mesmo em tempo útil.

O poder judicial, enquanto pressuposto do Estado de Direito goza dos atributos de independência e de imparcialidade. Sendo certo que a missão do juiz, enquanto titular do poder judicial, é a de solucionar litígios e não tanto a de exercer ou afirmar um poder do Estado, pelo menos é esta a filosofia que subjaz ao carácter do julgador no mundo anglo-saxónico, onde a jurisdição do Estado, enquanto função a ser por este exercida, se acha bastante esbatida. (NABAIS, 2011)

A função jurisdicional que tem sido observada como uma função estadual de soberania, não se compraz com a partilha dessa soberania com os particulares, sobretudo quando se reporta ao sector da justiça destinado a dirimir conflitos de natureza pública, conflitos que resultam de actos praticados por outros órgãos estaduais - justiça pública (administrativa e fiscal). (NABAIS, 2011)

Porém, esta aparente impossibilidade de partilha ou "indisposição" quanto a esta, acaba por esbarrar na enormidade de litígios que assomam aos tribunais judiciais e que por lá ficam uma eternidade sem qualquer tratamento. Tal situação leva a afirmações como esta, cheia de justeza, de Casalta Nabais: "Pelo que a abertura à arbitragem, incluindo no reduto formado pelo sector do direito dos impostos, se, por um lado, não põe em causa a ideia de Estado de Direito, por outro lado, parece constituir mesmo uma das formas pelas quais pode passar a sua concretização nos dias de hoje. Por isso, afigura-se-nos que essa via de resolução de litígios não pode, num quadro que se paute por um mínimo de realismo, ser liminarmente dispensada". (NABAIS, 2011)

\section{CONSAGRAÇÃO DA ARBITRAGEM VOLUNTÁRIA NA CONSTITUIÇÃO E NA LEI.}

Tecidas aquelas breves considerações gerais, voltemos a nossa atenção ao instituto da arbitragem voluntária que tanto constitui preocupação do legislador constituinte angolano, como do legislador ordinário.

Apesar de a arbitragem voluntária ter tido acolhimento no Código do Processo Civil -Título I do Livro IV (Tribunal Arbitral Voluntário), como é sabido, no ano de 2003, e fruto do recurso permanente a normas arbitrais de reconhecido gabarito internacional, para a resolução de litígios que pudessem ocorrer em sede de contratos comerciais celebrados entre agentes económicos angolanos ou entre estes e outras entidades nacionais e estrangeiras, foi aprovada a Lei da Arbitragem Voluntária, Lei n.ำ16/03, de 25 de Julho, que procedeu à revogação daquele Título do Código do Processo Civil.

Apesar do seu carácter quase que ancestral, o instituto da arbitragem voluntária raramente foi utilizado, no período do pós independência, pelo menos até ao surgimento daquela lei e mesmo alguns anos após a sua entrada em vigor. Mas mesmo volvidos 13 anos desde a sua vigência, o instituto da arbitragem continua a ser utilizado a medo, há ainda pouco conhecimento e confiança a respeito do seu funcionamento e das suas virtudes. E pelas vantagens que este instituto pode representar, em alternativa ao sistema judicial, José Semedo afirmou o seguinte: "Sem desmérito pelas características e vantagens da arbitragem, parece-nos que contribuem sobremaneira para que 
a arbitragem encontre um terreno fértil ao seu sucesso, as críticas que, quase universalmente são dirigidas aos tribunais judiciais, mormente, a lentidão do seu processualismo, a crescente descrença nas suas soluções e, acima de tudo, nos contratos internacionais, a ausência de legitimidade exclusiva de nenhum tribunal estatal para a solução dos litígios deles oriundos". (SEMEDO, 2009)

É no preâmbulo desta lei que se consagra que "a arbitragem constitui um mecanismo extrajudicial privilegiado não só pelos operadores privados como pelo próprio Estado ${ }^{3}$ para solução dos eventuais conflitos sobre os direitos patrimoniais, considerados disponíveis por lei, devido às enormes vantagens que Ihe são reconhecidas, designadamente, a sua celeridade e flexibilidade, bem como a liberdade das partes no processo de escolha e nomeação dos árbitros, aliados ao seu carácter sigiloso e propício à transacção".

Em 2006, numa atitude de incentivo e reforço ao papel da arbitragem voluntária, o Conselho de Ministros aprovou a Resolução n. ${ }^{034 / 06}$ de 15 de Maio, determinando o seguinte: "o Estado, nas suas relações com os cidadãos e com outras pessoas colectivas, deve activamente propor e aceitar a superação dos diferendos em que seja parte, com recurso aos meios alternativos de resolução de litígios." (artigo 2..$^{\circ}$. Mais adiante no artigo $5 .^{\circ}$ a Resolução estabelece que "no desenvolvimento das suas atribuições o Estado e outras pessoas colectivas públicas que integram a administração estadual indirecta, proponham e adoptem soluções concretas de mediação e de arbitragem como modalidades preventivas e alternativas de composição de litígios com os cidadãos, com as empresa e outras pessoas colectivas".

A Constituição de 2010 veio consagrar no artigo 174. - , mais propriamente no seu número 4. o recurso a outros meios de resolução de litígios além dos tribunais judiciais, inserindo-os na função jurisdicional: A lei consagra e regula os meios e as formas de composição extrajudicial de conflitos, bem como a sua constituição, organização, competência e funcionamento". Significa que tais meios extrajudiciais de conflitos, de entre os quais se encontra a arbitragem, cuja lei já estava em vigor, desde 2003, passaram a ter assento constitucional ao lado dos tribunais judiciais.

O que quer dizer que embora os tribunais judiciais tenham jurisdição atribuída pelo Estado e os tribunais arbitrais recebam tal poder jurisdicional das partes que intervêm no litígio, uns e outros detêm a função jurisdicional, pelo que não se estabelece entre eles qualquer relação de supra, infraordenação. Isto mesmo esclarece a Lei da Arbitragem Voluntária (LAV), quando define em que condições e momentos podem os tribunais judiciais pronunciar-se relativamente às decisões

\footnotetext{
${ }^{3}$ Assim o determina o n.o3 do artigo 1.o da LAV angolana: "O Estado e, em geral, as pessoas colectivas de direito público, só podem celebrar convenções de arbitragem nos seguintes casos: a) para dirimir questões respeitantes a relações de direito privado; b) nos contratos administrativos; c) nos casos especialmente estabelecidos por lei".

${ }^{4}$ Ao tratar da arbitrabilidade subjectiva dos litígios a LAV neste n.03 do artigo 1.. indica as situações em que o Estado e outras pessoas colectivas públicas podem recorrer à arbitragem. Como referem Manuel Gonçalves, Sofia Vale e Lino Diamvutu, Lei da Arbitragem Voluntária Comentada, Faculdade de Direito da Universidade Agostinho Neto, Luanda, 2014, p. 43, "Sempre que a administração actue despida do seu ius imperii, o litígio daí adveniente deve considerar-se um litígio de direito privado e, consequentemente, poderá ser submetido à arbitragem. Os diferendos resultantes de contratos administrativos que, atenta a sua natureza contratual e a sua corrente complexidade, incentivam o recurso a uma jurisprudência especializada na matéria objeto do contrato em questão, são campo privilegiado para a utilização da arbitragem (....."
} 
proferidas pelos tribunais arbitrais, quando uma das partes faça desencadear os mecanismos adequados.

Para Manuel Barrocas, a inserção no texto constitucional português dos tribunais arbitrais, mais propriamente no artigo 209.. , n. .2 , tal inserção não tem o intuito de integrar estes tribunais no sistema jurisdicional estadual, uma vez que não fazem parte do aparelho estadual, mas tão só de conferir dignidade constitucional a esses tribunais e ainda que o artigo da LAV que reconhece à sentença arbitral a mesma força executiva atribuída à sentença proferida por um juiz togado, não seja ferido de inconstitucionalidade. (BARROCAS, 2013) Esta não parece, porém, ser a posição maioritária da doutrina.

Embora a Constituição devesse mais abertamente referir-se à arbitragem, como mecanismo de resolução de litígios, preferiu-se que essa menção aparecesse diluída entre os demais meios de resolução de litígios. Contudo, a remissão que se faz para a lei ordinária, que contém com o detalhe necessário os parâmetros em que este instituto se move, parece não deixar dúvidas acerca dos objectivos pretendidos com a aplicação da arbitragem voluntária.

Faz todo o sentido que a arbitragem seja considerada uma alternativa aos tribunais judiciais, e faz todo o sentido, em face das imensas insuficiências dos resultados apresentados pelos tribunais judiciais na sua função de órgãos de soberania que exercem a justiça pública. Não é do desconhecimento de ninguém as inúmeras pendências que estes tribunais têm, a carência de magistrados judiciais, o carácter não especializado dos juízes, em face da complexidade das matérias que Ihes são dadas a julgar, e das sentenças que proferem, a morosidade processual, em face do excessivo formalismo que caracteriza o processo judicial, a natureza eminentemente contenciosa, podendo ser mitigada por disposições do processo civil, a carência de meios técnicos. Todos estes e outros aspectos ligados à estrutura e orgânica dos tribunais judiciais constituem fundamento do maior impulso que deve ser dado à arbitragem voluntária.

Vem a este propósito (das pendências existentes nos tribunais judiciais) abordar com algum detalhe o artigo 29. da Constituição, começando por avaliá-lo para depois responder à questão de saber se uma justiça como é a angolana, tem ido ao encontro e concretizado esse princípio que é, no fundo, um direito fundamental do cidadão angolano.

Comecemos, então, por transcrevê-lo: "1. A todos é assegurado o acesso ao direito e aos tribunais para defesa dos seus direitos e interesses legalmente protegidos, não podendo a justiça ser denegada por insuficiências de meios económicos. 2. Todos têm direito, nos termos da lei, à informaçãoo e consulta jurídicas, ao patrocínio judiciário e a fazer-se acompanhar por advogado perante qualquer autoridade. 3. A lei define e assegura adequada protecção do segredo de justiça. 4 . Todos têm direito a que uma causa em que intervenham seja objecto de decisão em prazo razoável e mediante processo equitativo. 5. Para defesa dos diretios, liberdades e garantias pessoais, a lei assegura aos cidadãos procedimentos judiciais caracterizados pela celeridade e prioridade, de modo a obter tutela efectiva e em tempo útil contra ameaças ou violações desses direitos".

Tem-se dito que o direito de acesso à justiça é o corolário do Estado de Direito, de facto o direito de acesso ao direito e aos tribunais confere aos cidadãos o direito de serem sujeitos num processo que seja célere, de obterem uma decisão de mérito, em prazo razoável, mediante um 
processo equitativo, onde cada parte tenha as mesmas oportunidades de exercer o seu direito de defesa, e de poder assistir à execução de decisão que for proferida pelo tribunal.

Para a materialização em alguma extensão do que se contém no texto deste artigo, necessário seria que o sistema de justiça assentasse em parâmetros diferentes, daqueles em que assenta actualmente.

No que se refere designadamente aos actos praticados pela Administração Pública atentatórios de direitos e interesses legitimamente protegidos dos cidadãos, como poderão estes fazê-los valer, quando o sistema de justiça administrativa se funda em diplomas que foram criados num contexto constitucional diferente do actual, como é o caso da Lei n.ำ/94, de 14 de Janeiro - lei da impugnação dos actos administrativos -, do Decreto-Lei n.-4-A/96, de 5 de Abril - que regulamenta o processo do contencioso administrativo -, do Decreto-Lei n.16-A/95, de 15 de Dezembro - que aprova normas de procedimento e da actividade administrativa, ou ainda a Lei n. $.8 / 96$, de 19 de Abril - da suspensão dos actos administrativos -.

Parece que se está perante diplomas que estando embora em vigor, se acham desajustados da realidade actual e em alguns casos atentam contra o sentido e orientação do texto constitucional actual.

Enquanto que o artigo 29. da CRA vai ao encontro de uma nova concepção de Administração Pública e do papel dos tribunais na administração da justiça, bem como dos direitos e interesses legalmente protegidos dos particulares, precisamente pela alteração da concepção da Administração Pública, os diplomas em que assenta o contencioso administrativo e toda a justiça administrativa datam de uma época em que o princípio da legalidade e o conceito de interesse público, serviam de apoio a uma Administração autoritária, concepção que voltamos a afirmar não é a preconizada na Constituição de $2010^{5}$.

Embora se saiba na prática que nada mudou e talvez, por isso mesmo, se têm mantido em pleno vigor aqueles diplomas legais, que em alguns casos têm sido ultrapassados por legislação posterior. Atente-se a título de exemplo o que se tem passado com o instituto da arbitragem, como mais adiante veremos.

Como afirma Marcy Lopes, citado por Cremildo Paca (2016, p. 54): "o objecto do contencioso administrativo angolano é a tutela da legalidade e do interesse público. A protecção dos direitos

\footnotetext{
${ }^{5}$ Como assinala Ana Mafalda Costa Francisco, A Arbitragem Tributária, dissertação de mestrado, Porto, 2012, pp. 7 e 8: "Tradicionalmente estabelecia uma relação de clara supremacia em relação ao cidadão, movimentando-se autoritariamente e utilizando o acto administrativo como principal forma de actuação. Tínhamos uma Administração Pública estritamente vinculada à lei, encontrando nela as justificações das suas decisões. Agora surge uma Administração Pública que se vê a braços com uma multiplicidade de atividades a prosseguir, que com o modelo tradicional de actuação não seria possível executar. Passa já não a actuar distanciada dos administrados como antes acontecia, tornando-se mais próxima dos cidadãos, procurando neles apoio para as diversas opções a adoptar - passa a usar mais mecanismos de concertação e cooperação como meio de prossecução do interesse público. De uma Administração Pública autoritária, despótica, utilizando o acto administrativo como principal meio de actuação passa-se a uma Administração Pública que actua junto dos particulares, preocupando-se com os seus interesses individuais, actuando conjuntamente e cooperativamente com os mesmos por meio, essencialmente, do contrato administrativo. Hoje lidamos com uma Administração já não tão imbuída dos seus poderes de autoridade, mas sim mais próxima dos particulares. (...) Acabando por se reconhecer a arbitragem como meio tendencialmente normal para a resolução de litígios emergentes dessa relação entre administração e administrados".
} 
subjectivos e interesses legalmente protegidos dos administrados é uma consequência da realizaçãoo da legalidade não sendo, todavia, o seu escopo principal"6.

Além disso, o sistema de contencioso administrativo angolano dá acolhimento ao papel de um tipo de juiz que não tem competência para condenar a Administração Pública a praticar o acto administrativo devido, limita-se a anular ou a declarar nulo tal acto (art..21.ำ do Decreto-Lei n..ㄴA/96). (PACA, 2008)

Cremildo Paca (2016, p. 56) , a respeito da interpretação que há-de ser dada ao artigo $29 . \stackrel{0}{\text { da }}$ CRA e à sua materialização ao nível da legislação ordinária, afirma que este artigo por conter o direito fundamental à tutela jurisdicional efectiva "imediatamente exequível, deve ser interpretado de acordo com o princípio constitucional da máxima força possível ao preceito constitucional, não se devendo restringir o seu conteúdo". Acrescenta ainda que: "O legislador, ao criar normas infraconstitucionais, deve esgotar a letra e o espírito daquele artigo".

A questão é a que referimos atrás, estão em aplicação normas, ao nível da legislação ordinária, já desajustadas, tornando-se necessário e urgente a sua adequação à realidade actual.

A essas limitações acresce a orgânica dos tribunais angolanos. Não existem tribunais administrativos nem tribunais fiscais e aduaneiros. O desempenho da missão que a estes estaria cometida foi deferida a salas e câmaras de tribunais comuns. O julgamento de casos de contencioso administrativo, fiscal e aduaneiro é realizado (quando é) nas salas do cível, administrativo, fiscal e aduaneiro dos Tribunais Provinciais e em recurso na câmara do cível, administrativo, fiscal e aduaneiro do Tribunal Supremo. Estas salas e câmaras têm sido consideradas especializadas, sabendo-se como se sabe que os juízes têm formação no domínio das ciências jurídico-civis.

A este respeito veja-se o que diz Cremildo Paca (2016, p. 52-53): "Quanto a nós, o problema não reside apenas no facto de ser ter optado pelo "monismo da judicatura". Também inquieta-nos a solução adoptada sobre a "especialização" da jurisdição administrativa. Além do mais, o Tribunal Supremo está dividido em Câmaras, uma delas a do Cível, Administrativo, Fiscal e Aduaneiro e exerce competência genérica e especializada. O exercício da competência genérica e especializada foi a solução encontrada para fundamentar a integração da jurisdição administrativa, fiscal e aduaneira nos tribunais comuns (...). É demasiado ambígua e prolixa a formulação legal para aferirmos que a Câmara e as Salas do Cível, Administrativo, Fiscal e Aduaneiro têm natureza especializada. Não existe especialidade onde há "assento legal de casamento" - até que a reforma as separe - entre o cível, administrativo, fiscal e aduaneiro. Por conseguinte, a Câmara e Salas se estruturam e funcionam como Câmara e Salas "de banda larga", onde cabem e se confundem as matérias de natureza cível, administrativa, fiscal e aduaneira. Por isso, reitera-se que este modelo de organização jurisdicional não cumpre a tarefa de especialização necessária, se atendermos ao facto de que deve existir uma fronteira entre a jurisdição comum e a jurisdição administrativa, fiscal e aduaneira. (...). Os processos judiciais desta natureza e de índole administrativa, fiscal e aduaneira são decididos por juizes de sensibilidade civilística, o que prejudica a adequada "especialização de

\footnotetext{
${ }^{6}$ Marcy Lopes, Estudos de Direito Público, Coimbra, 2001, p. 67, apud Cremildo Paca, Justiça Administrativa e Tributária - Angola, no prelo, p. 54
} 
competências para as causas administrativas" fiscais e aduaneiras, porquanto «julgar a administração é específico».

A tudo isto acrescentaria a falta de imparcialidade na tomada de decisões desses tribunais, chegando-se ao ponto de em litígios entre o particular e o ente público, aquele ver o seu direito ou interesse legítimo que tenha sido violado, não ser reconhecido, depois de longos e penosos anos de espera, ainda levando em cima com uma condenação em custas judiciais.

Um quadro como o acima apresentado, parece justificar a criação de um regime específico e autónomo não só para a jurisdição estadual nesses domínios, como na própria arbitragem, sendo certo que não obstante a lei ordinária que regula os sistema de justiça administrativa não permita a arbitragem voluntária como meio de resolução de litígios, senão em casos muito contados (como é a limitação imposta pelo artigo 71.을 do Decreto-Lei n.-94-A/96, de 5 de Abril: "É proibida a arbitragem nas acções derivadas de contratos administrativos que revistam a natureza de contratos económicos internacionais, desde que se verifiquem os requisitos exigidos pelo artigo 99. ․, n. ㅇ 2 e 5 do Código do Processo Civil"), é precisamente na legislação ordinária que se encontra inúmeros casos em que a arbitragem tem sido eleita com essa finalidade.

Esta discrepância de normas levaria a que se tecessem mais considerandos, mas como não é a razão de ser do tema sobre que escrevemos, limitamo-nos a dizer que haverá que existir maior cuidado em relação ao que se legisla. Mesmo que queiramos alinhar na modernidade dos institutos que ganham cada vez mais corpo e aceitação no mundo jurídico, porque a isso tem forçado a celeridade das relações que se estabelecem no comércio jurídico, o legislador ordinário angolano ao cumprir a não fácil missão de se actualizar, para se colocar ao lado dos demais ordenamentos jurídicos, haverá de ter a preocupação de olhar para trás e coadunar o que foi feito com o que tem de fazer-se, ao nível legislativo. E acima de tudo, levar a que se criem as estruturas adequadas para se poder por a funcionar e aplicar as modernas e apreciáveis leis que aprova, mas que ficam muitas vezes sem qualquer aplicabilidade, como que numa ilimitada e eterna vacatio legis.

Para culminar esta excursão breve que fizemos ao instituto da arbitragem voluntária, do ponto de vista da sua consagração no ordenamento jurídico angolano, ela não ficaria completa se não abordássemos a LAV na matéria que constitui o objecto deste estudo, mais propriamente se não olhássemos para o seu artigo 1.ํ, que contém algumas respostas para as perguntas que são formuladas a propósito da admissibilidade da arbitragem nos domínios administrativo e tributário. Esse enquadramento será feito em tese muito geral, pois no lugar próprio veremos como o legislador ordinário Ihes deu tratamento.

E sobre o que, desde logo, pretendemos discorrer é o sentido e o alcance do artigo 1. da LAV, quanto à possibilidade de ele encerrar estas matérias como susceptíveis de arbitrabilidade ${ }^{7}$. Ora parece que encontramos uma resposta positiva no n.ำ. e no n.ํํ deste artigo.

\footnotetext{
7 Sobre o conceito de arbitrabilidade ver: Ana Perestrelo de Oliveira, Arbitragem de Litígios..., cit., p. 9 e ss, Mariana França Martins, Curso de Resolução Alternativa de Litígios, Almedina, 2014, 3.a edição, pp. 135 e ss, Correia Fernandes Bartolomeu, Arbitragem Voluntária como Meio Extrajudicial de Resolução de Conflitos em Angola, Almedina, 2014, pp. 91 e ss., Manuel Gonçalves, Sofia Vale e Lino Diamvutu, Lei da Arbitragem Voluntária Comentada, Luanda, 2014, pp. 38 e ss.
} 
O n.ำ. deste artigo contém o que se denomina por arbitrabilidade subjectiva e também a arbitrabilidade objectiva que faz assentar no critério da disponibilidade de direitos. Segundo este número são não arbitráveis os litígios que estejam submetidos, exclusivamente, à resolução pela via judicial ou sujeitos à arbitragem necessária, a arbitragem que seja imposta pela lei.

O n.ํ 3 deste artigo 1.ำ confere ao Estado e às pessoas colectivas de direito púbico a faculdade de celebrarem convenções de arbitragem apenas em casos contados: a) para dirimir questões no âmbito do direito privado; b) nos contratos administrativos e c) em situações que sejam estabelecidas por lei. Trata-se igualmente do estabelecimento de arbitrabilidade subjectiva, em relação aos entes ali mencionados ${ }^{8}$.

Quanto ao que nos interessa, sem dúvida que o $n . \stackrel{3}{3}$ deste artigo admite a celebração de convenção de arbitragem nos contratos administrativos, celebrados com o Estado ou com outras pessoas colectivas de direito público.

Como pode observar-se trata-se de uma disposição que não vai ao encontro do que dispõe o regulamento do contencioso administrativo (Decreto-Lei $\mathrm{n} .{ }^{\circ} 4-\mathrm{A} / 96$, de 5 de Abril) que só admite 0 recurso à arbitragem em relação a contratos económicos internacionais 9 .

Isto só vem reforçar o que ficou dito mais atrás a respeito do carácter vetusto de tais disposições de carácter administrativo, que já há muito deveriam ter sido substituídas.

Contudo, achamos curioso que o legislador ordinário tenha feito remissão para esse regime, a propósito da arbitrabilidade dos contratos fiscais, em sede do Código do Processo Tributário (art. 92.o.). Outra disposição que deixa muitas reticências ao intérprete e senão mesmo ao aplicador da norma.

\section{RAZÕES QUE TÊM DETERMINADO A NÃO ACEITAÇÃO DO INSTITUTO NOS DOMÍNIOS ADMINISTRATIVO E TRIBUTÁRIO NO DIREITO INTERNO DE VÁRIAS ORDENS JURÍDICAS E FUNDAMENTOS QUE JUSTIFICAM A SUA ADMISSIBILIDADE.}

Importa, antes de se aflorar os argumentos contra e favor da introdução da arbitragem nos domínios administrativo e tributário, aduzir algumas considerações sobre o que se herdou em termos de princípios do Estado liberal e a força desses princípios na defesa dos direitos e interesses legalmente protegidos dos cidadãos.

Dos vários princípios que resultaram dos movimentos em prol da consagração dos direitos do homem e do cidadão, podem elencar-se: o princípio do consentimento prévio do imposto, da legalidade, da reserva de lei, da igualdade, da justiça, da imparcialidade, da capacidade contributiva e tantos outros.

Porém e como afirmam Ricardo Catarino e Luciano Filipo, "a reserva de lei é frequentemente objecto de abuso na forma como se legisla. A igualdade fiscal é ferida não apenas pelo carácter tendencialmente regressivo dos impostos sobre o consumo como pelas taxas nominalmente

\footnotetext{
${ }^{8}$ Ver por todos Manuel Gonçalves, Sofia Vale, Lino Diamvutu, Lei da Arbitragem Voluntária Comentada, Faculdade de Direito da universidade Agostinho Neto, Luanda 2014, p. 38 e ss.

9 Este conceito já mereceu alguma atenção por parte da doutrina interna, mas ao que parece o seu enquadramento está eivado de algumas reticências.
} 
progressivas dos impostos sobre o rendimento. Os níveis de carga fiscal há muito que deixaram de ser moderados. A capacidade contributiva é apenas um índice indicativo de tributação". (CATARINO; FILIPO, 2012, p. 7)

Há que não esquecer que as Constituições do mundo moderno e que aderiram ao modelo democrático, deram acolhimento ao conceito de democracia participativa, apelando por força disso à mais frequente participação dos cidadãos na gestão pública, falando-se hoje muito de parceiros sociais, em "formas de governação partilhada" e mesmo ao nível da "codecisão ou negociação legislativa". (CATARINO; FILIPO, 2012, p. 8)

Mas a dita debilidade da expressão da tutela dos direitos e interesses legalmente protegidos dos cidadãos não se verifica, somente, ao nível dos princípios, senão também e no plano prático, ao nível do exercício da administração pública da justiça, que podendo ser um factor de grande contributo para a tutela efectiva dos direitos e interesses legalmente protegidos dos cidadãos, aqui compreendidos os agentes económicos, os contribuintes e outros, velando pela observância das garantias que Ihes estão conferidas, tal não se verifica, pois ela "não cobre toda a realidade social; está longe de satisfazer as necessidades sociais; é lenta, cara e ineficiente; é fonte de custos burocráticos que pesam até nas decisões dos investidores externos." (CATARINO; FILIPO, 2012, p. 9)

A resistência que se tem verificado na inclusão da arbitragem no direito interno em domínios como o Direito administrativo e o Direito fiscal (e principalmente neste último) tem conhecido um certo abrandamento na resolução de conflitos internacionais, quando em causa estejam o Estado e outras pessoas colectivas de direito público a contracenar com empresas e particulares, em particular no direito internacional público e no direito comercial. Assim, por exemplo, o FMI e a ONU, aprovaram convenções que regulam conflitos em matéria fiscal internacional. Mas também a CNUDCl, aprovou em 1985, a Lei Modelo sobre a Arbitragem Comercial Internacional.

No plano internacional existem três domínios onde é usual a arbitragem tributaria: no seio da arbitragem comercial ou administrativa por vezes podem indidir sobre relações contratuais em que se discute direitos e obrigações relacionados com o cumprimento de obrigações fiscais de uma das partes e em que o tribunal arbitral é chamado a interpretar. O próprio Estado pode ser parte nesse tipo de contratos nos quais está em causa não os seus poderes tributários mas os seus direitos e obrigações como parte no contrato. Há ainda o caso das arbitragens no âmbito de contratos de investimento estrangeiro, onde surgem litígios relacionados com o lançamento de imposto pelo Estado hospedeiro. Depois ainda arbitragem tributaria internacional como meio de resolução de litígios surgidos entre autoridades tributárias de diferentes países, respeitantes por exemplo à interpretação de cláusulas em acordos de dupla tributação. A OCDE recomendou a inclusão de cláusulas arbitrais nessas convenções de dupla tributação visando uma resolução mais expedita e eficaz, quanto à interpretação e aplicação da lei fiscal. P.4-5.

A existência permanente de conflitos no mundo de negócios e o cada vez maior envolvimento de entres públicos e privados, no comércio jurídico, requer a entrada em funcionamento de meios mais expeditos, mas seguros, eficientes, eficazes e capazes de não defraudar a confiança dos 
sujeitos jurídicos, tudo são razões que têm justificado a abertura aos chamados mecanismos alternativos de resolução de litígios.

Deixámos dito mais atrás que a aceitação da arbitragem voluntária na resolução de litígios jus-administrativos e jus-tributários passou ou tem passado pela colocação de diversos obstáculos. Partamos primeiro para o domínio administrativo.

Um dos grandes obstáculos tem assentado na natureza pública do sujeito, que em face dessa sua característica, tem determinado o recurso à via de resolução pela jurisdição estadual. Aonde os litígios envolvendo sujeitos públicos são dirimidos por órgãos de soberania (tribunais administrativos e fiscais), originariamente vocacionados para a sua resolução, tornou-se impensável, o estabelecimento de convenções atribuindo essa missão a árbitros. O carácter imperativo do exercício da actividade desses órgãos, em ordem e obediência aos princípios da legalidade e do interesse público, tornava proibitiva a aceitação da via arbitral. Tentando explicar a razão de ser dos argumentos dos que perfilhavam esta posição José Luís Esquível (2011, p. 60) diz que a dificuldade "em aceitar que a Administração Pública, ligada a uma ideia de poder público, sujeita à legalidade administrativa e à realização do interesse público, possa por convenção, afastar a competência dos tribunais administrativos, criados justamente para apreciar litígios de natureza jus-administrativa, para submeter-se ao julgamento de árbitros".

Tal obstáculo tem sido rebatido em Portugal, onde se tem registado uma maior abertura à introdução da arbitragem nestes dois domínios do Direito, tanto a nível doutrinário como jurisprudencial, apontando no sentido de que nada obsta à aceitação da arbitragem, pois não existe qualquer "reserva de jurisdição estatal" no julgamento de casos que envolvam a Administração Pública, além disso, existem, na prática, matérias que são subtraídas ao poder de julgar dos tribunais administrativos e fiscais, sendo de relevar que o texto constitucional português considera o colégio arbitral como um verdadeiro tribunal (art.-209.9), inserido no elenco dos demais tribunais. A este respeito, como explica Ana Perestrelo de Oliveira (2007, p. 51), tal obstáculo fica a dever-se à "concepção, largamente ultrapassada, que via no recurso dos entes públicos à arbitragem um "golpe" na soberania estatal - esquecendo que a resolução arbitral de litígios é, ainda e sempre, uma resolução jurisdicional (...).

Um outro obstáculo prende-se com a sujeição da Administração Pública ao princípio da legalidade e do interesse público, bem como com a ideia da indisponibilidade dos poderes dos seus órgãos. Esta objecção foi levantada e defendida por João Caupers, que considerando as competências dos órgãos administrativos indisponíveis, pois não só não se tratam de direitos subjectivos, como além de que tais poderes não são conferidos em interesse próprio, mas da colectividade, não concebia a "entrega" de tais poderes a árbitros. A superação apresentada para este obstáculo situou-se tanto na aceitação de que o princípio da legalidade invocado não é posto em causa, havendo uma autorização legislativa geral para que se verifique a admissibilidade da arbitragem, como considerando que o árbitro é um julgador, a submissão a este de um litígio, não implica ou significa qualquer poder de disposição sobre a "situação controvertida". Embora de outra ordem, o mesmo se passa com o obstáculo colocado a propósito da arbitragem no domínio tributário, quanto à indisponibilidade do crédito fiscal, chegando-se à conclusão de que o árbitro à data em que 
julga a situação, o crédito não existe, mas a sua mera possibilidade. Por isso, a arbitragem não coloca em causa a indisponibilidade de tal crédito, porque ele só se concretiza após proferida a decisão arbitral.

Ainda um outro obstáculo se colocava quanto ao carácter inderrogável das normas relativas à competência dos tribunais administrativos. Ora, quanto a este, o facto de se admitir a inderrogabilidade de tais normas, ou melhor a validade de tais normas sobre competência não impede que em situações concretas ocorra a sua derrogação ou excepção por força da celebração de convenções de arbitragem, nos seus dois formatos. (OLIVEIRA, 2007)

Há quem, na doutrina portuguesa tenha questionado se a arbitragem não colidia com o princípio da tutela jurisdicional efectiva, previsto no artigo $200^{\circ}$ da CRP (que tem a sua "réplica" no artigo 29.ำ da CRA). Os defensores da introdução da arbitragem, e não são poucos, foram bem certeiros nas suas posições, entre eles destaca-se Jorge Lopes de Sousa, que a propósito defendeu o seguinte: " é um imperativo básico essencial de um Estado de Direito a implementação de meios eficazes de resolução jurisdicional de conflitos, inclusivamente aqueles que se geram entre entidades públicas e os cidadãos (...)", por isso, "tendo em conta que a "decisão em prazo razoável" é indissociável de tal tutela (artigo 20.ํ, n.ำ, da CRP), ao menos exigir-se-lhe-á (ao Estado aditamento nosso)que não entrave a possibilidade de ela ser obtida (...) pelos meios alternativos que constituem os tribunais arbitrais, pelo menos na medida e enquanto estiver em condições de concretizar aquela satisfação"10. (SOUZA apud FIGUEIRAS, 2011, p. 65)

Em matéria tributária têm sido colocados mais uns ingredientes, para tentar dificultar a abertura à arbitragem, mas pelo menos em Portugal foi dado um importante passo, com a entrada em vigor da Lei $n .-93-B / 2010$, de 28 de Abril, que aprovou o Orçamento para o ano de 2010, cujo artigo $124 .{ }^{\circ}$ continha uma autorização legislativa para a introdução da arbitragem como forma alternativa de resolução jurisdicional de conflitos, em matéria tributária (" A Arbitragem Tributária visa reforçar a tutela eficaz e efetiva dos direitos e interesses legalmente protegidos dos contribuintes, devendo ser instituída de modo a constituir um direito dos contribuintes" - ficou consagrado um direito potestativo do contribuinte em relação ao recurso à arbitragem) e que já começou a dar os seus frutos, com a entrada em vigor do Decreto-Lei n.010/2011 de 20 de Janeiro, que aprovou o regime jurídico da arbitragem tributaria (RJAT), como um regime autónomo, ao que já se achava estabelecido no Código do Processo dos Tribunais Administrativos (CPTA).

No que respeita a obstáculos, desde logo, a consideração da indisponibilidade e irrenunciabilidade do crédito tributário, sendo que na opinião de alguns doutrinários, a arbitragem põe em causa esse carácter do crédito fiscal.

Estamos a citar, naturalmente, o que se levantou a propósito do tema em Portugal, por ser o ordenamento mais próximo e porque em Angola, apesar de o Código Geral Tributário de 2014, consagrar a indisponibilidade do crédito fiscal (art. $.61 .^{\circ}$ ) admite-se a arbitragem tributária (art. $.92 .$. do Código do Processo Tributário), embora de forma, quanto a nós muito tímida, sem que à volta do

\footnotetext{
10 Jorge Lopes de Sousa, Algumas Notas sobre o Regime da Arbitragem Tributária, apud Cláudia Sofia Melo Figueiras, Arbitragem em Matéria Tributária... (cit.), p. 65.
} 
assunto se tenha estabelecido a polémica típica de quando se admitem inovações à legislação doméstica, que sempre se coloca e acontece lá fora.

Ora, voltando à polémica registada em Portugal, a indisponibilidade do crédito tributário achase prevista no artigo $30 .^{\circ}$, n. ${ }^{\circ} 2$ da Lei Geral Tributária, nos seguintes termos: "O crédito tributário é indisponível, só podendo fixar-se condições para a sua redução ou extinção com respeito pelo princípio da igualdade e legalidade tributária".

Este princípio decorre ou coloca-se no plano dos demais princípios que regem a actividade da Administração Pública, desde logo, os princípios da legalidade, da igualdade, da justiça, da imparcialidade e da boa-fé.

$\mathrm{Na}$ medida em que a Administração Pública (Tributária) não é titular dos direitos que decorrem da obrigação tributária, pois entenda-se ser mera gestora deles, em nome e em representação da colectividade, deles não pode dispor e nesse particular reside a indisponibilidade do crédito tributário.

Como se sabe: "os impostos são um atributo de soberania, uma manifestação de máxima publica potestas (sublinhado nosso) facto que, para alguns, poderia fazê-los escapar à competência dos árbitros. Todavia, isso não impede a utilização de conceitos indeterminados em norma e regimes substantivos concretos, disciplinadores da relação tributária, nem o recurso à discricionariedade técnica". (CATARINO;FILIPO, 2012, p. 16-17)

Contudo, a questão da inarbitralidade de conflitos que envolvam o crédito tributário só se colocaria se estivesse em causa a disponibilidade do crédito tributário pela Administração. O que acontece é que quando se submete um conflito que se prenda com o direito de crédito sobre o agente passivo, aquele ainda não se acha concretizado na "esfera jurídica da Fazenda Pública". Como afirma Nuno Filipe Henriques, citando Jorge Lopes de Sousa: "A irrenunciabilidade e indisponibilidade do crédito tributário não se verifica no momento em que ainda é possível reagir contra o ato de liquidação da Administração Tributária, a não ser assim, não seria viável a existência de qualquer

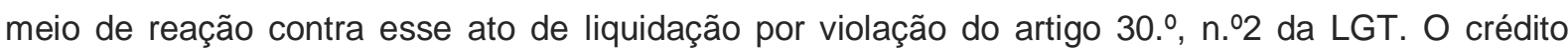
tributário, apenas se concretiza na esfera jurídica da Fazenda Pública, quando já não é possível a existência de nenhum meio de reação legal contra esse ato de liquidação". (HENRIQUES, 2013, p. 16-17)

Está aqui em causa a natureza meramente declarativa do acto tributário, relativamente à existência do crédito tributário. Partindo a decisão arbitral de um juízo interpretativo da existência de tal crédito, este juízo não é incompatível com a natureza meramente declarativa do acto de liquidação. A decisão arbitral porque assente numa função jurisdicional é semelhante à de qualquer tribunal judicial tributário, no que respeita à determinação da certeza da existência do crédito tributário a favor da Administração Tributária. (HENRIQUES, 2013)

Sobre esta questão Ricardo Catarino e Luciano Filipo defendem dever a arbitragem ser admitida no Direito tributário, uma vez que este não se configura como área rigorosa de vinculação legal. Haja em vista que as relações entre o fisco e o contribuinte já não obedecem mais, em bom rigor a uma natureza vertical, situando-se em espaços de disponibilidade. Tal é o caso, dizem, "dos contratos fiscais, dos conceitos indeterminados, das margens de livre apreciação, dos espaços 
verdadeiramente discricionários atribuídos à administração tributária, por razões de praticabilidade e de maior liberdade na aplicação da lei fiscal. É também o caso da aplicação de métodos de determinação indirecta do rendimento, em que se permite a participação, o diálogo e, de algum modo, o ajuste das realidades com o contribuinte". (CATARINO;FILIPO, 2012, p. 17)

Questionou-se igualmente que a admissibilidade da arbitragem colocaria em causa o princípio da capacidade contributiva. Tem-se defendido que ao invés de por em causa tal princípio a arbitragem há-de determinar o grau de capacidade contributiva, quando for chamada a pronunciar-se sobre os factos que tiverem ocorrido e que conduzam ou conduziram a essa capacidade e em que medida ela se apresenta.

Sobre a alegada incompatibilidade entre a arbitragem e o Direito público, sob o argumento de que a defesa do interesse público, pelas autoridades administrativa vinculadas que se acham ao princípio da legalidade, só pode ser controlada por juízes togados, defende-se que estes não são mais sérios na observância do controlo dos dinheiros públicos do que um árbitro, sendo certo que tanto aqueles como este devem no exercício da função jurisdicional aplicar o direito, bem como administrar a justiça. (CATARINO;FILIPO, 2012)

A terminar não se poderá deixar de mencionar as vantagens que têm sido reconhecidas à arbitragem voluntária, de um modo geral, mas que com toda a certeza tais vantagens relevam nestes dois domínios do Direito, de que temos vindo a ocupar-nos: o Direito administrativo e o Direito fiscal (ou mais latamente entendido, tributário, uma vez que como se sabe além do tributo imposto, estudado em sede do Direito fiscal, que é o Direito dos impostos, outros tributos existem que carecem de tratamento ao nível das normas do Direito, daí o Direito tributário).

Pois então, de forma breve, enumeremos as vantagens que de um modo ou de outro são reconhecidas à arbitragem voluntária: celeridade ( do ponto de vista da parte que possa ficar vencida, há-de ser encarada como uma desvantagem) em face da lentidão dos processos pendentes nos tribunais judiciais, que enfermam de uma excessiva morosidade, meio de descongestionamento dos tribunais judiciais, o carácter especializado dos árbitros permite-lhes fazer face à "elevada e crescente complexidade técnica" das questões objecto da lide, confidencialidade, que é um atributo benéfico para a arbitragem comercial, mas que para a arbitragem no domínio administrativo e tributário, por causa da natureza pública de um dos sujeitos deve pelo contrário ser pública.

Ademais e ainda quanto à morosidade dos tribunais judiciais, olhando para a realidade angolana, cuja estrutura orgânica judicial apenas admite salas e câmaras e não tribunais autónomos com vocação para as matérias administrativa e tributária, o problema ainda é mais agravado, pelo que se impõe deitar mão à arbitragem.

\section{A ARBITRAGEM VOLUNTÁRIA EM ALGUNS CONTRATOS ADMINISTRATIVOS: CONCESSÃO DE DIREITOS PETROLÍFEROS E MINEIROS, DE INVESTIMENTO PRIVADO (ESTRANGEIRO), DE EMPREITADAS DE OBRAS PÚBLICAS E DE PARCERIAS PÚBLICO-PRIVADAS.}

Já lá vai o tempo em que o contrato era uma figura objecto de resistência por parte da Administração Pública. 
O contrato administrativo é uma categoria do Direito administrativo, que configura uma relação administrativa de natureza contratual, é um negocio jurídico em que pelo menos concorrem dois actos de manifestação de vontade, sendo que uma delas pertence necessariamente à Administração Pública.

Não está aqui em causa a equiparação ou igualdade de posições entre as partes envolvidas, mas o nivelamento das vontades declaradas, "a igual valia das vontades", como afirma Sérvulo Correia $^{11}$. (CORREIA apud OLIVEIRA, 2005, p. 10)

Ora é uma nova filosofia adoptada na concepção da Administração Pública que passou a que se admita esta como uma Administração Pública paritária ou concertada ou ainda prestadora ou prestacionista, onde a penetração da figura do contrato, que antes obedecia a uma lógica de contratualização vertical, cedeu espaço ao carácter bilateral e sinalagmático do contrato. Como afirma Casalta Nabais, a propósito da admissibilidade da figura do contrato, nas relações jusadministrativas: "Na verdade, a igualdade das partes (se é que podemos utilizar esta expressão relativamente equívoca) que o contrato requer não é a igualdade de posição das partes (a aequalitas posicional), mas a igualdade referida directamente à prestação (a aequalitas prestacional), de modo que a prestação de uma das partes seja justificação bastante da da outra parte". (NABAIS, 1994, p. 23)

Depois de se ter dito que o regime de contencioso administrativo aparece como regime subsidiário e que a regra no domínio administrativo é a proibição da arbitragem, sendo permitida, apenas nos contratos económicos internacionais, e depois de ainda se terem referido as principais vantagens da arbitragem, como meio alternativo de resolução de conflitos, é importante que se proceda a uma averiguação sobre em que "águas tem navegado" o legislador ordinário e bem assim os destinatários das normas em vigor sobre arbitragem voluntária.

Vejamos, contudo, o que nos dizem os comentadores da LAV angolana a respeito da arbitrabilidade de contratos que se inscrevem no domínio administrativo, contratos administrativos, portanto: "Os diferendos resultantes de contratos administrativos que, atenta a sua natureza contratual e a sua corrente complexidade, incentivam o recurso a uma jurisprudência especializada na matéria objecto do contrato em questão, são campo privilegiado para a utilização da arbitragem. De entre eles, há que salientar os contratos relativos a investimento estrangeiro em que o Estado seja parte (designadamente, os contratos de concessão, de partilha de produção no âmbito dos recursos naturais, de sociedade, ou outro tipo de contratos que instituam parcerias público-privadas) ou em relação aos quais o Estado se tenha vinculado a apoiar o investimento aí previsto (designadamente através de benefícios fiscais, incentivos financeiros ou contrapartidas específicas).(GONÇALVES; VALE; DIAMVUTU, 2014, p. 43-44)

Esta averiguação vai ser feita, tendo em conta as disposições legais que existem em vários sectores da actividade económica angolana e que contemplam a arbitragem como meio de resolução de conflitos.

11 Cfr. José Manuel Sérvulo Correia, Legalidade e Autonomia Contratual nos Contratos Administrativos, Almedina, 1987, p. 347, apud Gustavo Henrique Justino de Oliveira, Arbitragem e as Parcerias Público-Privadas, in Revista Electrónica de Direito Administrativo Económico, n.2, Maio-Julho, 2005, Salvador/Baía, p. 10. 
Comece-se pelo sector petrolífero, onde há mais tempo (ou se calhar não) se tem operado com contratos administrativos, mais propriamente de concessão, nas modalidades mais em uso, entre nós, o contrato de partilha de produção, celebrados ao abrigo da lei do investimento privado (estrangeiro).

É bom que se diga que neste sector importa contar com análise do ou dos artigos da lei das actividades petrolíferas, mas também com a lei do investimento privado.

Nos termos do artigo 89. da Lei das Actividades Petrolíferas, determina-se o seguinte: "1. Os litígios que eventualmente ocorram entre o Ministério de tutela e as licencidas ou entre a Concessionária Nacional e as suas associadas sobre matérias estritamente contratuais devem ser resolvidos por consenso das partes, segundo os princípios da boa fé e da equidade ou equilíbrio de interesses das partes. 2. No caso de não ser obtido consenso entre as partes, os litígios devem ser resolvidos por recurso a arbitragem, nos termos que forem estabelecidos na licença de prospecção e nos contratos celebrados ao abrigo do artigo 14.․ 3. O Tribunal Arbitral deve funcionar em Angola, aplicar a lei angolana e a arbitragem ser conduzida em língua portuguesa."

Antes de se tecer qualquer comentário, importa que se veja o conteúdo do artigo 14.․․ já que é para este artigo que $o$ artigo sobre a arbitragem remete.

Este artigo é importante porque nele se define as modalidades de contratos que podem ser celebrados entre a concessionária nacional e outras entidades. Assim: "1. A Concessionária Nacional pode associar-se com entidades nacionais ou estrangeiras de comprovada idoneidade e capacidade técnica e financeira, mediante prévia autorização do Governo. 2 A associação pode revestir as seguintes formas: a) sociedade comercial; b) contrato de consórcio; c) contrato de partilha de produção. 3. É permitido também à Concessionária Nacional o exercício das operações petrolíferas através de contratos de serviços com risco".

A via arbitral nos termos em que ela se desencadeia, devem ser estabelecidos na licença de prospecção e nos contratos típicos, de sociedade, de partilha de produção, de consórcio e tal como

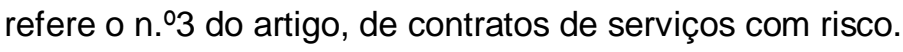

Em total discordância com o artigo $71 . .^{\circ}$ do Decreto-Lei $\mathrm{n}$. -4-A/96, a Lei das Actividades Petrolíferas acolhe a arbitragem como meio de resolução de conflitos num sector que foi e embora hoje, tendencialmente, menos, continua a ser importante para o país. Tendo, porém, tido acesso ao modelo de contrato de partilha de produção que por norma é utlizado no sector, embora nele se refira que a lei substantiva é a lei angolana, a lei do processo é integrada pelas as regras da UNICITRAL, nenhuma referência se fazendo à lei da Arbitragem Voluntária, quanto aos procedimento e processo. Também aqui se denota o não cumprimento das disposições legais em vigor, e embora já se tenha aludido às razões disso (a falta de confiança e de segurança jurídica na lei de um país onde tudo pode acontecer), continua-se sem perceber o afastamento da lei angolana para regular o conflito, caso ele ocorra.

No sector mineiro, é o Código Mineiro que dispõe sobre a faculdade que assiste às partes de escolherem o meio de administração de justiça na resolução de conflitos. Este código não refere (que tenhamos identificado), tal como o faz a lei das actividades petrolíferas, especificamente qualquer regra sobre arbitragem. Porém, como se trata de um domínio sujeito a licenciamento e implica a 
associação entre pelo menos o ente público e outra entidade nacional ou estrangeira, pública ou privada, os contratos que sejam ou venham a ser celebrados acabam por cair no âmbito da lei do investimento privado, a Lei $n . .914 / 15$, de 11 de Agosto, que no seu artigo 46., , n. .9 . e 4. determina que: "3. Nos contratos de investimento privado é lícito convencionar-se que os diferentes litígios sobre a sua interpretação e a sua execução possam ser resolvidos por via arbitral. 4. Nos casos referidos no número anterior, a arbitragem deve ser realizada em Angola e a legislação aplicável ao contrato e ao processo deve ser a lei angolana.

Os contratos de investimento privado são nitidamente contratos administrativos, assim o define a lei do investimento privado no artigo $46 .^{\circ},{ }^{\circ}{ }^{\circ} 1$ : "O contrato de investimento tem natureza administrativa e como partes, o Estado angolano, representado pelo órgão da Administração directa ou indirecta a quem o titular do Poder Executivo delegue e o investidor". Já em 2008 Lino Diamvutu defendia que a natureza administrativa do contrato de investimento distingue-o do contrato de direito privado pela finalidade a que se destina, no atendimento do interesse público. Portanto, o contrato de investimento é celebrado entre o Estado e o investidor privado (nacional ou externo). Os investidores enquadrados em regime contratual apresentam em grande medida a realização de um interesse público, como acontece nos contratos administrativos tipificados ${ }^{12}$. (DIAMVUTU 2008 apud PACA, 2016)

Nesta norma denota-se uma maior clareza quanto à lei aplicável à arbitragem, que não se encontra na lei das actividades petrolíferas e no modelo contratual de partilha de produção.

Entendemos, contudo, que há que existir uma uniformização nas regras e nos procedimentos, em face do rigor que deve sempre presidir no plano da contratação pública, sabendo-se como se sabe que quando as partes estão desavindas, existe a conveniência de que tudo se paute pela maior clareza. Em causa estará o interesse público, é em ordem a este que essa clareza deve ser observada.

Mas, ainda que a referência à lei da arbitragem voluntária seja feita naquela norma da lei do investimento privado, não cremos que um investidor estrangeiro se sinta confiante ao entregar o conflito a um tribunal arbitral que se vá reger pela lei angolana. Nem até mesmo quando sejam escolhidas regras de organizações internacionais o fazem sentir seguro, porque se os mecanismos da lei processual angolana (que não a arbitral) forem accionados de forma pervertida, de nada valerão os mecanismos que regem a arbitragem. Evidentemente, que se está a colocar uma hipótese, mas esta decididamente não é meramente académica.

Contudo terá andado bem o legislador ordinário angolano ao definir o recurso à arbitragem segundo aqueles moldes. O que fica por saber é a sua eficácia em termos de aplicação.

No que concerne à arbitragem nos contratos de empreitadas de obras públicas, rege a lei dos

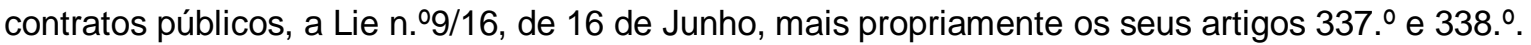

O artigo $337 .^{\circ}$ que tem por epígrafe, "tribunal arbitral", estabelece o seguinte: "1. No caso de as partes optarem por submeter o diferendo a tribunal arbitral, o respectivo compromisso deve ser assinado antes de expirado o prazo de caducidade do direito. 2. O tribunal arbitral é constituído e

\footnotetext{
${ }^{12}$ Cfr. Lino Diamvutu, Estudos de Direito Comercial Internacional, Caxinde, Luanda, 2008, pp. 27 a 28, apud, Cremildo Paca, Justiça Administrativa... , cit. p. 141.
} 
funciona nos termos da Lei sobre a Arbitragem Voluntária. 3. Quando o valor do litígio não for superior ao nível 3 da Tabela de Limites de Valores constantes no Anexo II da presenta Lei, pode ser designado um só árbitro".

O artigo $338 .^{\circ}$ cuja epígrafe é "processo arbitral", determina: "1. O processo arbitral é simplificado, nos seguintes termos: a) Há unicamente dois articulados: a petição e a contestação; b) Só podem ser indicadas duas testemunhas por cada facto contido no questionário; c) A discussão é escrita. 2. Proferida a decisão e notificada às partes, o processo é entregue ao órgão responsável pela regulação da construção civil e obras públicas, com conhecimento do órgão responsável pela regulação e supervisão da contratação pública, onde fica arquivado, competindo a este serviço decidir tudo quanto respeite aos termos da respectiva execução por parte das entidades administrativas, sem prejuízo da competência dos tribunais para a execução das obrigações do empreiteiro, devendo ser remetida ao juiz competente cópia da decisão do tribunal arbitral, para efeitos do processo executivo".

No n.1 do primeiro artigo parece partir-se do princípio que as partes contratantes decidem recorrer à arbitragem já depois do contrato estar em execução (compromisso arbitral), pois fala-se ali em caducidade de direito, certamente por aferição ao disposto no artigo 329.․ Mas há que admitir que as partes possam ter no contrato de empreitada de obras públicas inserido a convenção de arbitragem, na modalidade de cláusula compromissória. Nada obsta a que assim tenha sido.

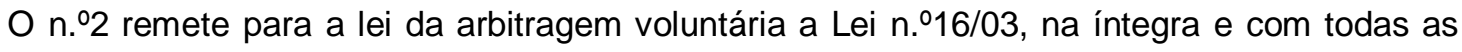
consequências, mas relativamente à constituição e funcionamento do tribunal arbitral.

Já o artigo 338..$^{\circ}$, que se refere ao processo arbitral pretendeu estabelecer um processo próprio, seguindo de perto as regras do processo sumário do processo civil, quanto aos articulados a apresentar (n.ำ). O n.2 deste artigo é que parece um bocado confuso. Diz-se que depois de a decisão ser proferida, o tribunal arbitral entrega o processo a dois órgãos da Administração Pública (o que regula o sector da construção e o que regula a área da contratação pública), sendo que num deles (o órgão da contratação pública) o processo fica arquivado e a quem compete decidir sobre os termos da execução da decisão arbitral (presume-se), no entanto sem prejuízo de ao tribunal competente para mandar executar a decisão arbitral ser enviada cópia desta, para o desencadeamento da correspondente execução.

A pergunta que nos ocorre fazer é se a lei da arbitragem voluntária se aplica, apenas na fase de constituição do tribunal arbitral? E se após esse momento ela deixa de aplicar-se, valendo as regras que se contêm naquele artigo 338 ?

Depois assiste-se aqui a uma dualidade de procedimentos, após ter sido proferida a decisão, o tribunal arbitral notifica as partes e entrega o processo aos órgãos administrativos já mencionados, um deles responde pelas obrigações que lhe disserem respeito, sendo certo de que valerá aqui dizer que se o tribunal arbitral condenar a entidade pública, este órgão fará com que a decisão seja cumprida por essa entidade pública. Porém, quando a parte condenada for o empreiteiro, o tribunal arbitral deve remeter ao tribunal judicial competente, cópia da decisão arbitral para efeitos da sua execução. Olhando para o que dispõe a lei de arbitragem voluntária, parece que esta determina 
claramente os termos de todo o processo arbitral e designadamente os detalhes processuais a seguir após o pronunciamento da decisão arbitral.

Até aqui e por falta de uniformidade ou de um regime específico para a arbitragem na contratação pública, assistimos a estas variantes, que representam tudo menos uniformidade no sistema.

Mas, entremos agora no regime de arbitragem aprovado para os contratos de parceria público-privadas.

Este regime está contido na Lei $\mathrm{n} . \stackrel{\circ}{2} / 11$, de 14 de Janeiro, que no seu artigo 20., sob a epígrafe "processos arbitrais" dispõe o seguinte:

"1. Os litígios emergentes das relações estabelecidas no âmbito das parcerias públicoprivadas, podem ser submetidos à arbitragem, nos termos da Lei Sobre Arbitragem Voluntária, em vigor. 2. Quando, nos termos do contrato de parceria já celebrado seja requerida a constituição de um tribunal arbitral para a resolução de litígios entre as partes, o serviço ou entidade que representa o parceiro público no contrato de parceria deve comunicar, imediatamente, aos titulares dos departamentos ministeriais da economia e da tutela sectorial, a ocorrência desse facto, fornecendo todos os elementos que se revelem úteis ao acompanhamento do processo. 3. Com vista ao acompanhamento do processo arbitral, os titulares dos departamentos ministeriais da economia e da tutela sectorial podem determinar, mediante despacho conjunto, a constituição de uma comissão de negociação. 4. Devem ser remetidas, periodicamente, à entidade directamente incumbida de proceder ao acompanhamento do respectivo processo arbitral, cópias dos actos processuais praticados por qualquer das partes pelo tribunal, bem como pareceres técnicos e jurídicos e quaisquer outros elementos relevantes para a compreensão, desenvolvimento ou desfecho da lide.".

Está-se aqui perante outro formato do que deva ser a arbitragem ou melhor o processo arbitral em sede de contratos de parcerias-público privadas.

E um formato, que diga-se em abono da verdade muito sui generis, e que faz pressupor uma intromissão das entidades administrativas no processo arbitral.

A pergunta que logo se coloca é: se ao invés das partes nas circunstâncias previstas no n.ํ2. daquele artigo tiverem de recorrer a um tribunal judicial os procedimentos seriam os mesmos? É que entendendo como se entende que o tribunal arbitral na sua missão de julgar goza de um poder jurisdicional, que the é conferido pelas partes, que razão assistirá a que tenha de haver acompanhamento do processo arbitral, com entrega de cópias dos actos processuais, no decurso do processo a entidades administrativas? Ademais que garantias é que isso dá do ponto de vista da imparcialidade e independência de que tem a função de julgar?

Depois não se percebe o conteúdo do n.ำ, quanto à criação de uma comissão de negociação. Então se há um tribunal arbitral a julgar a lide, não é este competente para a tramitação do processo? Há que chamar pessoas estranhas ao processo para negociar a lide? Os árbitros numa audiência preparatória não conseguem ouvir e perceber se as partes querem negociar ou não? Ou será que essa comissão de negociação que se propõe intervém, mas fora do processo, após a tentativa de conciliação arbitrada pelo tribunal arbitral? Se é isso, não está dito claramente e no contexto do artigo, entende-se que a pretensão é outra. 
Se a intenção é que a resolução de litígios que ocorram neste tipo de contratos seja desenvolvida, segundo a lei da arbitragem voluntária, como se refere no n.ำ1, os restantes números do artigo deixam dúvidas de que seja isso que se pretenda.

Verifica-se que além da falta de uniformidade no modo como estes regimes sobre arbitragem aparecem delineados, cada um sendo mais estranho do que os outros, sendo certo que o que está mais condicente porque se baseia verdadeiramente nela, é o que dispõe a lei do investimento privado, continua a assistir-se a um desconhecimento do que seja a arbitragem e a sua finalidade.

Cremos que continua a olhar-se para o tribunal arbitral, não como um julgador, à semelhança do que fazem os juízes togados, ou talvez melhor, porque estes não são especializados e os árbitros devem sê-lo, mas como um agente cujo juramento pela imparcialidade e independência, no entender de quem assim pensa, vai poder por em causa o interesse público.

Ora também aqui, é preciso que exista um conhecimento abalizado do que é o interesse público, não o confundindo com o interesse do governo, mas aliando e avaliando-o segundo o interesse da colectividade, da Nação.

Há por isso que ter presente e não esquecer, nem confundir que o fundamento em que se apoia a arbitragem voluntária no domínio do Direito público assenta na caracterização dos tribunais arbitrais como tribunais capazes de exercer uma função verdadeiramente jurisdicional. Note-se que a função jurisdicional pertence ao Estado mas o exercício dessa função pertence a outros entes, designadamente aos árbitros. $O$ facto de terem a seu cargo a função jurisdicional, de declararem o direito, aos tribunais arbitrais não se coloca qualquer obstáculo que os impeça de dirimir conflitos entre o Estado e os particulares.

É preciso ainda não esquecer a utilidade pública da função da arbitragem, justificando-se assim que à decisão do tribunal arbitral sejam concedidos os efeitos próprios da sentença judicial.

\section{OS CONTRATOS FISCAIS E A ARBITRAGEM VOLUNTÁRIA NO CÓDIGO DO PROCEDIMENTO TRIBUTÁRIO.}

O Código Geral Tributário prevê no seu artigo 19. , sob a epígrafe "Contratos Fiscais", a figura dos contratos fiscais, na modalidade de benefícios fiscais: "1. Os benefícios fiscais podem ser concedidos por contrato, nos casos e condições expressamente estabelecidos por Lei. 2. Os benefícios fiscais contratuais visam o equilíbrio económico e social do País, o desenvolvimento local e o incentivo ao investimento privado. 3. Quando os benefícios fiscais provenham de contrato de concessão, a isenção limita-se, salvo disposição contratual em contrário, aos rendimentos provenientes do objecto da concessão e às aquisições de bens que se destinem especificamente à consecução do mesmo objecto. 4. Quando os benefícios fiscais tenham sido concedidos por contrato, a tributação depende da sua resolução, anulação ou declaração de inexistência ou nulidade do negócio jurídico.".

Os contratos fiscais são, antes de tudo, contratos da Administração, visto esta ser uma das partes. Segundo Filipa Neto Mariano, "os contratos fiscais constituem contratos administrativos especiais, por natureza, por consagrarem contratos de atribuiçãoo económica, com objecto passível 
de acto administrativo, em suma, os contratos fiscais têm a natureza de contratos administrativos. (MARIANO, 2011, p. 13)

Casalta Nabais classifica os contratos fiscais em: contratos relativos à determinação da matéria colectável, contratos relativos à cobrança do imposto e contratos relativos à atribuição de desagravamentos fiscais (estáticos - relativos a situações passadas e atribuídas por razões políticas, sociais, de defesa, diplomáticas, religiosas, culturais, etc - e dinâmicos - relativos a situações que se pretendem desenvolver por razões sobretudo económicas ${ }^{13}$. (NABAIS, 1994, p. 104/123)

Para Cremildo Paca, "os contratos fiscais constituem uma espécie do género contrato administrativo, regulado nos artigos 120. e seguintes do Decreto-Lei ํㅡ 16-A/95, de 15 de Dezembro. Adaptando a definição desta lei, no que toca aos contratos administrativos, pode-se dizer que os contratos fiscais são os acordos de vontade entre a Administração Tributária e os particulares, com vista à constituição, modificação ou extinção de uma relação jurídico-tributária, tendo em vista à realização de um interesse público.

Os contratos fiscais são negócios jurídicos firmados entre os contribuintes e a Administração fiscal, tendentes a constituir, modificar ou extinguir uma relação ou situação jurídico-fiscal. Neste sentido, Filipa Neto Mariano diz que o Direito Fiscal não tem sido indiferente à figura do contrato fiscal, existindo verdadeiros contratos que modificam, criam ou extinguem relações de direito fiscal. (PACA, 2016, p. 240)

A prevalência que é dada aos benefícios fiscais no Código Geral Tributário, leva-nos a citar algumas das normas internas que versam sobre a atribuição de tais benefícios: a Lei do Investimento Privado (Lei n.․14/15, de 11 de Agosto), Código do Imposto Industrial (Lei n.19/14, de 22 de Outubro), Código sobre a Aplicação de Capitais, Diploma Legislativo n.ำ230, aprova o Regulamento para a liquidação e cobrança do Imposto sobre Sucessões e Doações e Sisa, Lei das Micro, Pequenas e Médias Empresas (Lei n..-30/11, de 13 de Setembro), Código Mineiro (Lei n.ำ31/11, de 23 de Setembro), Lei do Mecenato (Lei $n . .8 / 12$, de 12 de Janeiro), Lei sobre a Tributação das Actividades Petrolíferas (Lei n. $13 / 04$, de 24 de Setembro).

O Código do Processo Tributário, aprovado pela Lei n.-22/14, de 5 de Dezembro, contém uma norma respeitante à arbitragem, o artigo 92.. , só que tal artigo restringe imenso o âmbito da arbitragem. Assim e segundo os seus dizeres: "As partes nos contratos fiscais apenas podem convencionar a arbitragem sobre as questões relacionadas com a interpretação, validade ou inexistência e execução das suas cláusulas nos termos previstos no Regulamento do Processo de Contencioso Administrativo e em leis tributárias especiais".

Ora, a disposição que nesse regulamento se refere à arbitragem é o artigo $71 .$. , que por sua vez faz uma remissão para o artigo 99.. , n..$^{\circ}$ S 2. e 5. do artigo 99. do Código do Processo Civil.

Cremildo Paca (2016, p. 244) não entra a fundo na questão da arbitragem voluntária no domínio tributário, limitando-se a dizer que se trata de um regime limitado, "pois só é admitida a arbitragem nos contratos fiscais em termos muito apertados", na medida em que ela só pode incidir nos domínios designados no artigo 92. do Código do Processo Tributário e que este remete para o

\footnotetext{
${ }^{13}$ Nota de rodapé 352 .
} 
regime do processo do contencioso administrativo e de outras leis tributárias especiais, o modo de estabelecimento da convenção de arbitragem entre a Administração Tributária e os particulares.

É importante, contudo que se diga mais. Desde logo que se identifique essa remissão para o regulamento do contencioso administrativo cujo artigo 71. se refere à arbitragem, mas que só a admite se incidir sobre contratos económicos internacionais, remetendo este regime, por sua vez, para o artigo 99., n. 오 2 e 5 do Código do Processo Civil.

Numa palavra, não se estabelece um regime de arbitragem no domínio tributário. O legislador tão somente se limitou a prever uma norma relativa aos contratos fiscais ou melhor às suas cláusulas sem fazer qualquer alusão à lei da arbitragem voluntária, que funcionaria a título subsidiário, não tendo havido a preocupação de delimitar e detalhar mais quais os parâmetros em que deverá moverse a arbitragem no domínio tributário. Porque remeter o regime da arbitragem tributária para o regime do processo do contencioso administrativo que se situa num foro completamente distinto, nada se fez, tendo em conta que o regime previsto para a arbitragem é um regime até mais simplificado.

Não se percebe a volta que o legislador deu ao remeter para aquele regime, que por sua vez remete para o Código do Processo Civil, em circunstâncias muito contadas, sem nunca fazer menção à lei da arbitragem voluntária.

Lino Diamvutu (2016, p. 113-114) em relação a esta matéria afirma que "o artigo 92.. do Código do Processo Tributário, aprovado pela Li n. ${ }^{\circ 22 / 14}$, de 5 de Dezembro, refere que "as partes dos contratos fiscais apenas podem convencionar a arbitragem sobre questões relacionadas com a interpretação, validade, inexistência e execução das suas cláusulas". Os contratos fiscais podem ser celebrados por ocasião da determinação da matéria colectável, tanto em sede de transacções fiscais, como em sede de benefícios fiscais". Faz ainda referência a disposições de desagravamento fiscal contidas quer na lei que aprovou o Código das Execuções Fiscais, a Lei n.ำ0/14, de 22 de Outubro

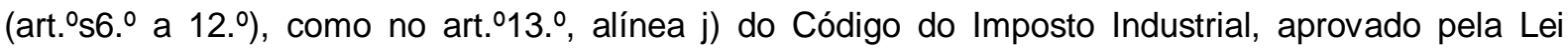
n. $-19 / 14$, de 22 de Outubro. O autor, apoiando-se, nas afirmações de Ana Perestrelo de Oliveira, considera que possa admitir-se a arbitrabilidade de questões fiscais quando no âmbito de arbitragem entre particulares de natureza civil ou comercial surja uma questão fiscal incidental. Admite também que um tribunal arbitral possa conhecer, no âmbito de um litígio contratual, as implicações que se coloquem ao nível do direito fiscal relativas ou decorrentes do cálculo de uma indemnização, por força da não execução de um contrato. Apesar de estas soluções poderem ter aceitação, em termos de arbitrabilidade tributária, noutros ordenamentos jurídicos, designadamente, o português e o francês, não temos a certeza de que elas possam ter o mesmo desfecho no direito angolano, devido ao facto de a arbitragem estar confinada aos contratos fiscais, naqueles apertados limites. Já, por exemplo, nos questionamos se a avaliação da validade ou inexistência de uma cláusula de um contrato fiscal possa conduzir os árbitros a fazer um juízo sobre a sua legalidade ou seja se os árbitros podem "controlar" a legalidade de uma cláusula, no âmbito desse contrato.

Os comentadores da LAV não entraram a fundo na questão da arbitrabilidade de litígios no domínio tributário, limitaram-se a dar uma informação sobre a admissibilidade da arbitragem no domínio tributário, identificando o carácter essencialmente público das normas fiscais (querendo dizer certamente tributárias) e apontando tal situação como a razão da habitual exclusão delas em relação 
ao foro arbitral. Numa altura em que ainda não havia sido publicado o Código do Processo Tributário de 5.12.2014. Mais adiante e comentando no domínio da arbitrabilidade subjectiva, a que se refere o n..-3, do art.- 1. da LAV, os comentadores citam como exemplo, a sujeição do Estado à lide arbitral, quando seja parte num contrato de investimento estrangeiro (contratos de concessão, de partilha de produção no âmbito dos recursos naturais, de sociedade ou de outro tipo de contratos que instituam parcerias públco-privadas) admitindo a hipótese de nesse tipo de contratos poderem conter cláusulas sobre incentivos/benefícios fiscais e aduaneiros susceptíveis de serem objecto de apreciação por árbitros. Utilizando a expressão empregada pelos comentadores: "As controvérsias que possam surgir quanto à implantação do contrato de investimento poderão ser submetidos a arbitragem (...)". (GONÇALVES; VALE; DIAMVUTU, 2014, p. 44).

\section{RECOMENDAÇÕES}

As recomendações expendidas abaixo, com as necessárias adaptações poderão servir como sugestões ao estabelecimento de um regime para a arbitragem tanto administrativa como tributária.

Deverá haver muita ponderação no regime que vier ser estabelecido no domínio da arbitragem tributaria que não apenas fiscal. Ela é permitida, ao abrigo do artigo $92 . .^{\circ}$ do Código do Processo Tributário, mas nada se diz relativamente ao modo como ela deve ser exercida efectivamente, pois a remissão que se faz para o contencioso administrativo que a proíbe é o mesmo que haver exoneração da pretensão de que mesmo nos domínios referidos no código se instale a via arbitral como meio de resolução de litígios.

A lei da arbitragem voluntária não é adversa a esse acolhimento (art.ำ.ํㅜ, n.ำ). Seria bom, para melhor adequar esse regime de aplicação da arbitragem ao domínio tributário, que além dos princípios, regras e procedimentos em que ela se vai mover, se legislasse sobre o estatuto dos árbitros e se definisse se o mais aconselhável é optar pela arbitragem institucionalizada, sendo ainda aconselhável que as instituições vocacionadas para a sua aplicação, denominadas centros de arbitragem não se circunscrevessem, em regime de exclusividade, a centros constituídos por entidades estatais, como é caso do CREL do ministério da justiça e dos direitos humanos, mas que pudessem ser actores nessa missão outros centros de arbitragem, desde que definidas claramente e para todos as regras de actuação, oferecendo-se, assim, um maior grau de confiança ao sujeito passivo - o contribuinte - que ao se ver envolvido num litígio com a Administração Pública na sua própria casa, poderá à partida e com justa razão colocar reservas quanto à justeza e à justiça dos árbitros que compõem o tribunal arbitral. Daí que seja muito importante no estatuto deontológico do árbitro, outro regime que é preciso aprovar, definir bem quais os requisitos, deveres, direitos, impedimentos e âmbito de actuação. Com vista a que se evitem favorecimentos a qualquer das partes, principalmente à Administração Pública, como se vê acontecer ao nível dos tribunais judiciais.

Deverá proceder-se, na delimitação do objecto do processo arbitral ao alargamento do âmbito da arbitragem tributária (à prática de certos actos tributários) e afastando, assim, o seu confinamento aos contratos fiscais, principalmente, na modalidade de benefícios fiscais, nos termos em que se acha consagrada no CPT. 
Definir-se claramente se o julgamento deve basear-se exclusivamente no direito constituído, afastando-se a aplicação da equidade.

Proceder-se à definição do modo de constituição do tribunal arbitral, à semelhança do que já acontece na LAV, mas sempre na perspectiva de uma arbitragem institucionalizada.

Definirem-se, de entre outras matérias, normas sobre princípios aplicáveis ao processo arbitral, sobre a admissibilidade ou não de recurso da decisão arbitral (a regra em Portugal é a irrecorribilidade, apenas sendo permitido recurso para o Tribunal Constitucional, nos casos e na parte em que a sentença arbitral recuse a aplicação de qualquer norma com fundamento na sua inconstitucionalidade ou aplique a norma cuja inconstitucionalidade tenha sido suscitada...(PALMA, 2010)), sobre o regime de anulação da sentença, seus fundamentos e atribuição de força executiva a esta, sobre a existência de uma segunda instância arbitral (esta hipótese já tem sido colocada, como forma de se evitar as demoras na apreciação dos recursos, quando sejam permitidos, e das acções de anulação das decisões arbitrais), sobre o custo da arbitragem, que hão-de ser ponderados de modo a que não constituam obstáculo ao seu recurso, enquanto meio útil e alternativo de resolução de litígios em face das pendências e demoras dos tribunais comuns.

\section{CONCLUSÕES:}

1. A arbitragem no domínio administrativo e tributário, embora consagrada no ordenamento jurídico nacional, aparece tratada de forma não uniforme, e com pouca consistência no Direito administrativo.

2. No Direito tributário a única disposição que se refere ao instituto deixa um espaço lacunoso, que se tentou preencher recorrendo ao contencioso administrativo.

3. Por sua vez, neste regime, a única norma que trata da arbitragem proíbe-a, enquanto regra, para dar permissão à sua aplicação no domínio dos contratos económicos internacionais, tão somente. O que significa que nos contratos de direito interno ela não teria hipóteses de singrar.

4. A vigência de normas que já há muito deveriam ter sido revogadas, como é o caso dos diplomas referentes a matéria administrativa, estão a ser ultrapassadas por normas contidas em leis posteriores.

5. Estas pretendendo acompanhar a evolução do comércio jurídico, contracenam, entretanto, aqui e ali com tais normas desajustadas do e no tempo.

7. Impõe-se, pois, a necessidade de legislar trazendo à luz do dia um regime jurídico único para a arbitragem em direito administrativo.

8. Sendo certo que igualmente, esse passo também se impõe, para a arbitragem tributária estabelecendo-se um regime jurídico autónomo com a definição das regras propostas nas recomendações deixadas mais atrás, neste breve estudo.

9.Tanto num domínio como no outro a arbitragem que se propõe é a institucionalizada, com vista a que se confira maior transparência ao procedimento, evitando-se assim interferências pouco recomendáveis ao exercício da arbitragem. 
10. A criação de regimes específicos para a arbitragem nos domínios do Direito aqui tratados, ladeados, por medidas que contribuam para a maior segurança jurídica, confiança e garantia dos operadores económicos, públicos e privados, contribuintes e cidadãos em geral, constituirá uma forma de dar "efectividade" ao princípio da tutela efectiva, previsto no artigo $29 .^{\circ}$ da Constituição angolana, que no final das contas é não mais, e como se tal não bastasse, do que um direito fundamental.

11. Por fim, a opção por julgar ou decidir segundo o direito constituído, na arbitragem, deitará por terra o argumento de que se trata de um instituto que leva à desjuridificação do processo tributário, como já tem sido considerado por alguma doutrina.

\section{REFERÊNCIAS}

BARROCAS, Manuel Pereira. Manual de Arbitragem, Revisto e Actualizado, LAV 2011, 2. a edição, Almedina, 2013.

BARTOLOMEU, Correia Fernande. Arbitragem Voluntária como Meio Extrajudicial de Resolução de Conflitos em Angola, Almedina, 2014.

BRAZ, Mário Rui Antunes. O Regime da Arbitragem Tributária, dissertaçãoo de mestrado, ISCAL, Lisboa, 2011.

CAMPOS, Diogo Leite de. A Arbitragem em Direito Tributário, in Estudos Jurídicos e Económicos em Homenagem ao Prof. Doutor António de Sousa Franco, Vol I, Edição da Faculdade de Direito da Universidade de Lisboa, Coimbra Editora, 2006.

A Arbitragem Voluntária (Jurisdição dos Cidadãos) nas Relações Tributárias, I Congresso do Centro de Arbitragem da Cãmara de Comércio e Indústria Portuguesa, ACL, Almedina, 2008.

CATARINO, João Ricardo; FILIPO, Luciano Gomes Filipo. Ainda a Propósito da Arbitragem no Direito Tributário: um Estudo de Direito Comparado sobre a sua Admissibilidade em Portugal e no Brasil, in Revista de Finanças Públicas e Direito Fiscal, Ano V, n.o 2 - verão, Almedina, 2012.

DIAMVUTU, Lino. A Convenção de Arbitragem no Direito Angolano, Instituto de Cooperação Jurídica da Faculdade de Direito de Lisboa, Almedina, 2016.

ESQUÍVEL, José Luís. Os Contratos Administrativos e a Arbitragem, apud, Cláudia Sofia Melo Figueiras, Arbitragem em Matéria Tributária: à Semelhança do Modelo Administrativo?, dissertação de mestrado, Universidade do Minho, Escola de Direito, Outubro de 2011, p. 60, disponível em https:// repositorium.sdum.uminho.pt/.../1/Cláudia\%20Sofia\%Melo\%20Figueiras.pdf, acedido em Novembro de 2016.

FIGUEIRAS, Cláudia Sofia Melo. A Arbitragem em Matéria Tributária: à Semelhança do Modelo Administrativo?, dissertação de mestrado, Universidade do Minho, Escola de Direito, Outubro, 2011, https://repositorium.sdum.uminho.pt/.../1/Cláudia\%20Sofia\%20Melo\%20Figueiras.pdf.

FONSECA, Isabel Celeste M. A Arbitragem na Contratação Pública em Portugal: uma Realidade com Futuro?, Universidade do Minho

FRANCISCO, Ana Mafalda Costa. A Arbitragem Tributária, dissertação de mestrado, Universidade Católica Portuguesa, Porto, 2012.

GONÇALVES, Manuel; VALE, Sofia; DIAMVUTU, Lino. Lei da Arbitragem Voluntária. Comentada, Faculdade de Direito da Universidade Agostinho Neto, Luanda, 2014.

GOUVEIA, Mariana França. Curso de Resolução Alternativa de Litígios, 3. a edição, 2014. 
HENRIQUES, Nuno Filipe Jesus. Arbitragem Tributária: um Contributo para a Reallzação da Justiça Tributária?, dissertação de mestrado, Universidade Católica Portuguesa, Escola de Lisboa, 2013.

INOCÊNCIO, Flávio. Benefícios Fiscais e Planeamento Fiscal, Revista da Faculdade de Direito da Universidade Agostinho Neto, Número Especial Comemorativo, coord. Elisa Rangel Nunes, Luanda, 2014.

MARIANO, Filipa Neto.Contratos Fiscais: Regime e Natureza, dissertação de mestrado, FDUNL, Fevereiro 2011.

NABAIS, José Casalta. - Contratos Fiscais, Reflexões Acerca da sua Admissibilidade, Stvdia Ivridica, 5, Boletim da Faculdade de Direito de Coimbra, Coimbra Editora, 1994.

. Reflexão sobre a Introdução da Arbitragem Tributária, in Revista da PGFN, Ano I, n.1, 2011, http/www.pgfn.fazenda.gov.br/revista-pgfn/ano-1-numero-/integral.pdf.

OLIVEIRA, Ana Perestrelo de. Arbitragem de Litígios com Entes Públicos, Almedina, 2007.

OLIVEIRA, Gustavo Henrique Justino de. A Arbitragem e as Parcerias Público-Privadas, Revista Electrónica de Direito Administrativo Económico, n.2, Maio-Julho, 2005.

OTERO, Paulo Otero. Admissibilidade e Limites da Arbitragem Voluntária nos Contratos Públicos e nos Actos Administrativos, II Congresso do Centro de Arbitragem da Câmara do Comércio e Indústria Portuguesa, ACL. Almedina, 2009.

PACA, Cremildo Paca. Justiça Administrativa e Tributária - Angola, 2016, no prelo.

. Direito de Contencioso Administrativo Angolano, Coimbra, Almedina, 2008.

PALMA, Clotilde Celorico. O Orçamento do Estado para 2010 e a Arbutragem em Matéria Tributaria, Revita TOC n.ำ124, Julho 2010.

POULSON, Lazarino. As Parcerias Público-Privadas na Arte de Governar, Casa das Ideias, 2011.

SEMEDO, José Antônio Lopes. A Arbitragem Voluntária em Angola: Quadro Normativo e Perspectivas, Centro de Arbitragem Comercial, II Congresso do Centro de Arbitragem da Câmara de Comércio e Indústria Portuguesa, Intervenções, ACL, Almedina, Junho 200

SILVA, Manuel Pereira da. Contencioso Administrativo Angolano. As Garantias dos Particulares no Contencioso Administrativo Angolano, dissertação de mestrado, UAL, Lisboa, 2005.

SOUZA, Jorge Lopes de. Comentário ao Regime Jurídico da Arbitragem Tributária, in Guia da Arbitragem Tributária, coord.: Nuno Villa-Lobos e Mónica Brito, Almedina, 2013

\section{LEGISLAÇÃO CONSULTADA}

Constituição da República Angola

Lei dos Contratos Públicos

Código Geral Tributário

Código do Processo Tributário

Código Mineiro

Lei das Actividades Petrolíferas

Revista do Direito [ISSN 1982-9957]. Santa Cruz do Sul, v. 3, n. 53, p. 153-180, set./dez. 2017. https://online.unisc.br/seer/index.php/direito/index 
Lei da Tributação das Actividades Petrolíferas

Lei do Investimento Privado

Lei das Parcerias Público-Privadas

Lei do Mecenato

Código do Imposto Industrial

Código sobre a Aplicação de Capitais

\section{COMO CITAR ESSE DOCUMENTO:}

NUNES, Elisa Rangel. Panorâmica e extensão da arbitragem voluntária nos domínios administrativo e tributário em Angola. Revista do Direito, Santa Cruz do Sul, v. 3, n. 53, dez. 2017. ISSN 1982-9957. Disponível em: <https://online.unisc.br/seer/index.php/direito/article/view/11366>. Acesso em: . doi:http://dx.doi.org/10.17058/rdunisc.v3i53.11366. 